地 第 2 輯

第 41 巻 (1988) 97-102 頁

\title{
跡津川断層周辺のブーゲ異常と地凯構造
}

\author{
金沢大学理学部地学教室* 大久保義弘** - 古 瀬 慶 博 - 河 野 芳 輝 \\ (昭和 63 年 1 月 14 日受付; 昭和 63 年 3 月 8 日受理)
}

\section{Bouguer Anomalies and Crustal Structure Models around the Atotsugawa Fault, Central Japan}

\author{
Yoshihiro Окиво, Nobuhiro Furuse and Yoshiteru Kono \\ Department of Earth Sciences, Faculty of Science, Kanazawa University \\ Marunouchi 1-1, Kanazawa-shi 920, Japan \\ (Received January 14, 1988; Accepted March 8, 1988)
}

\begin{abstract}
Crustal structure models from the Noto Peninsula to the Hida mountains area crossing the Atotsugawa fault were estimated based on both detailed gravity anomaly and explosion seismological data. The results are as follows;

(1) Minor changes of short wavelength Bouguer anomalies were observed across the Atotsugawa fault. This is due to small density differences of rocks around the fault. However, a locally high anomaly zone remained along the fault.

(2) Variation of long wavelength Bouguer anomalies across the fault was about 12 to $20 \mathrm{mgal}$ per $10 \mathrm{~km}$.

(3) Estimated crustal structure models indicated that the deeper subsurface structure changes suddenly under the fault. It suggests that the Atotsugawa fault is situated at the border of large scale variation of crustal structure between the Hida mountains and the Noto peninsula regions.
\end{abstract}

\section{§1.はじめに}

跡津川断層は, 中部日本北西部の立山と白山とを結ぶ 線上, 東北東 - 西南西に伸びる長さ $60 \mathrm{~km}$ 以上の右横 ずれの卓越した活動度 $\mathrm{A}$ 級の活断首である［松田 (1966), 活断首研究会 (1980)]. この断首は, 中部日本南 西部の北西 - 南東方向に伸びる左横ずれの阿寺断首とと もに，日本を代表する活断首である。

跡津川断層において起こった最近の地震は, 安政 5 年 (AD 1858) の飛越地震 (M 6.9) であり [松田 (1966), 宇 佐美・他 (1979)]，130 年近く経過した現在も，余震活 動が活発である [和田ら (1979)]. 最近, 跡津川断層中央 部の宮川でトレンチ調查が行なわれ, 飛越地震等過去 10 回以上の活動が確認された[跡津川断首掘削調查団 (1983)].

このような活動度の高い典型的な活断首について,

昭和 57 年 10 月 6 日発表

昭和 58 年 4 月 26 日発表

$*$ 个920 金沢市丸/内 $1-1$

**現所属：岐阜県立中津高等学校
ブーゲ異常をもとに地款構造を議論することは, 断首運 動等を解明する上で必要なことと考えられる.

以下に述べる様に, 重力デー夕に基づいて活断層のス ケールで議論できるようになったのは, 国土地理院 [GeOdETIC DePARTMENT (1985)], 金属鉱業事業団 (1972, 1976, 1978), 金沢大学 [Kono et al. (1982), 河 野 - 他 (1982)], 名古屋大学 [Үамамото et al. (1982)], 東京大学地震研究所, 地質調查所等による, 詳細な重力 データが中部日本において蓄積されてきたことによる.

これらのデータは, IGSN 71 系, つまり JGSN 75 系 [国 土地理院 (1976)] で統一的に整理され, 地形補正済みの ブーゲ異常図（補正密度 2.67）としてまとめられている [Kono et al. (1982)]. 地形補正には国土地理院による $500 \mathrm{~m}$ メッシュ平均標高データ［河野 (1978) に詳しく 説明]を用い, 測定点のまわり約 $80 \mathrm{~km}$ 四方について, 河野・久保 (1983) の方式に基づいて地形補正を行なっ てある. 本研究で用いた密度 $2.67 \mathrm{gr} / \mathrm{cm}^{3}$ は, 北陸地域 の基盤岩類（花岡岩・变麻岩類）に対する密度測定値 （96 個）[古瀬・河野 (1982)］の平均値 $2.70 \mathrm{gr} / \mathrm{cm}^{3}$ に 




Fig. 1. Bouguer anomaly map in the northwestern part of central Japan [simplified from Kono et al. (1982)]. Contour interval is 10 mgals. Density is assumed to be $2.67 \mathrm{~g} / \mathrm{cm}^{3}$. Hatched line: major active fault; $\mathrm{H}$ : high gravity anomaly; L: low gravity anomaly; HAK: Mt. Hakusan; TAT: Mt. Tateyama; NOR: Mt. Norikura; SEK: Mt. Sekidosan; HOD: Mt. Hodatsu; HIM: Himi; TOY: Toyama; ITO: Itoigawa; KAN: Kanawaza; TAK: Takayama; FUK: Fukui; USI: the Ushikubi fault; MOZ: the Mozumi fault; ATO: the Atotsugawa fault; MIB: the Miboro fault; ATE: the Atera fault.

極めて近い値である. 本報告では，これらの測定データ を用いて, 跡津川断渞とブーゲ異常との関係, およびそ の地壳構造モデルについて論ずる.

\section{§2. 跡津川断層周辺のブーゲ異常分布}

北緯 $35^{\circ} 40^{\prime} \sim 37^{\circ} 40^{\prime}$, 東経 $136^{\circ} \sim 138^{\circ}$ の範囲の地 形補正を施したブーゲ異常 (以下, 単にブーゲ異常と略 す）図を Fig. 1 に示す.この範囲内にある陸域の重力測 定点は約 5500 点である. 全体の測定点間隔は約 $2 \mathrm{~km}$ であるが, 跡津川断層周辺では約 $500 \mathrm{~m}$ である. 測定点 の分布については古瀬・河野 (1984)を参照されたい. さらに Fig. 1 中の跡津川断層周辺の四角形 $\mathrm{ABCD}$ の領 域について, 詳細なブーゲ異常図を Fig. 2 に示す. 図に おける稠密な測定点は主として金属鉱業事業団 (1972, 1976, 1978) によるあのである. その他は， Үамамото et al. (1982)（南部), Kono et al. (1982)（北部）および

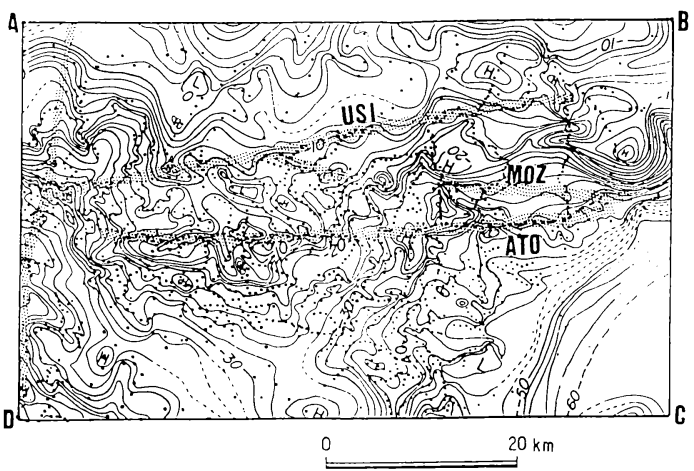

Fig. 2. Bouguer anomaly around the Atotsugawa fault within the $A B C D$ region in Fig. 1 . Contour interval is 2 mgals. USI: the Ushikubi fault; MOZ: the Mozumi fault; ATO: the Atotsugawa fault.

国土地理院によるものである.これらのブーゲ異常の特 徵とよび解釈を，局地的なむのと広域的なものとに分け て述べる。

\section{1 局地的なブーゲ異常分布}

一般に, 局地的な短波長のブーゲ異常変化は浅い所の 構造によるものであると考えることができる. Fig. 2 の 跡津川断層周辺のブーゲ異常分布をみると，断層をはさ んで北側のブーゲ異常值は南側のものより相対的に大き い傾向を示すが, 断層そのものを境としての垂直変位に 伴う短波長の急激なブーゲ異常変化は断層東端部を除い て顕著ではない．この原因は断層での垂直変位があって あ断層をはさんでの密度差が小さいためと考えられる。

Fig. 3 に簡略化して示した地質分布 [HIROKAWA et al. (1978)]を見る限り，跡津川断層周辺には“基盤”之よば れる花崗岩や变成岩, 先第三紀堆積岩 (主として手取首) が広く分布し，断層を境としての密度差はほとんどない と思われる. 地質学的観察によれば, 跡津川断首の垂直 変位量は $1 \mathrm{~km}$ 位下の北側の相対的隆起であるといわれ るが [松田 (1966)], 垂直変位がいくらあっても, 表層付 近に密度差がない場合は短波長のブーゲ異常变化として は現れにくい．またこのことは跡津川断層西半部におい て, 断層の北側と南側のすぐ近傍の上部地款に有意な速 度構造の差がない［和田・他 (1979)］こととも矛盾しな い.

次に，断層の横ずれ変位について検討を行なってみ る. Fig. 2 のブーゲ異常図は広域的な長波長のブーゲ異 常と局地的な短波長のブーゲ異常とが重ね合わさったも のである.このため局地的なブーゲ異常を論ずるにはそ れらを分離する必要がある，そこで広域的な傾向を 2 次 曲面で近似し，ブーゲ異常値からその值を差し引き，残 




Fig. 3. Simplified geological map around the Atotsugawa fault (simplified from HiroKAWA et al., 1978). 1: Quaternary sediments; 2: Tertiary sedimentary rocks; 3 : Mesozoic/ Palaeozoic sedimentary rocks; 4: Volcanic rocks; 5: Granitic/Metamorphic rocks; Solid line: Atotsugawa fault.

差重力異常を求めた. それを Fig. 4 に示す.このブーゲ 異常のコンターは断層西半部において, 断層に沿って閉 じている. 断層沿いの西半部で約 $10 \mathrm{mgal}$ の高重力異 常となる.これは断層の破砕帯に沿って高密度の岩体が 貫入しているためではないかと考えられる．規模は小さ いがこれと似た傾向は全磁力異常にもみられ, 磁化率が 周囲より大きい物質が断層に沿って貫入していると推定 される [村上・他(1984)]. 一方, 阿寺断層でこれと同様 な解析が江坂・古本 (1981) により行なわれたが，そこ では逆に負の重力異常帯が断層の破砕帯に沿って分布す る. 両断層におけるこうした特長の違いについては今後 検討する必要があろう.

\section{2 広域的なブーゲ異常分布}

中部日本全体のブーゲ異常の一つの特徵は, 河野 (1983) が指摘し,「飛驒三角形」と名付けたように, 跡津 川断層 - 飛驒山脈 - 阿寺断層にほぼ平行な, 三角形のコ ンターパターンが見られることである。この三角形は標 高 $1000 \mathrm{~m}$ 以上の地形分布と屯良く対応している [河野 (1983)]. この三角形内にみられる強い負の異常は, 主 に, 高い山地は地款が厚いというアイソスタシーの考え で理解できる [古瀬・河野 (1984)].

跡津川断層の走向に注目すると糸魚川の西方から砺波 丘陵を経て, 福井西方に伸びる高重力異常带が断層の走

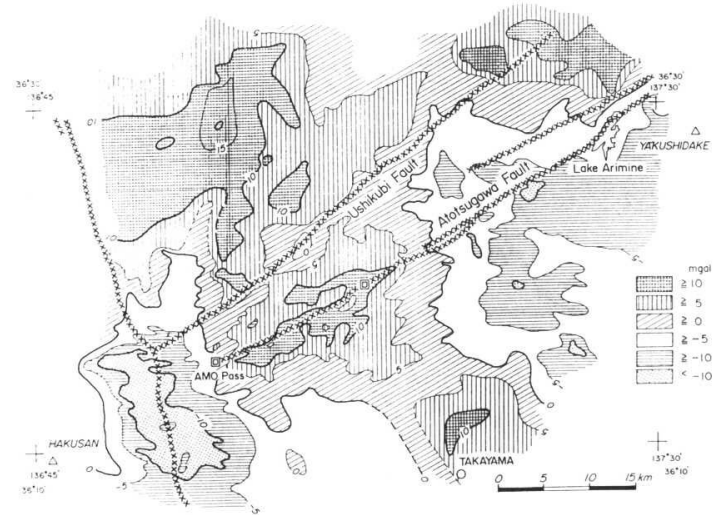

Fig. 4. Residual Bouguer anomaly. Contour interval is 5 mgals. Notice corners of the figure are a little different to those of Fig. 2.

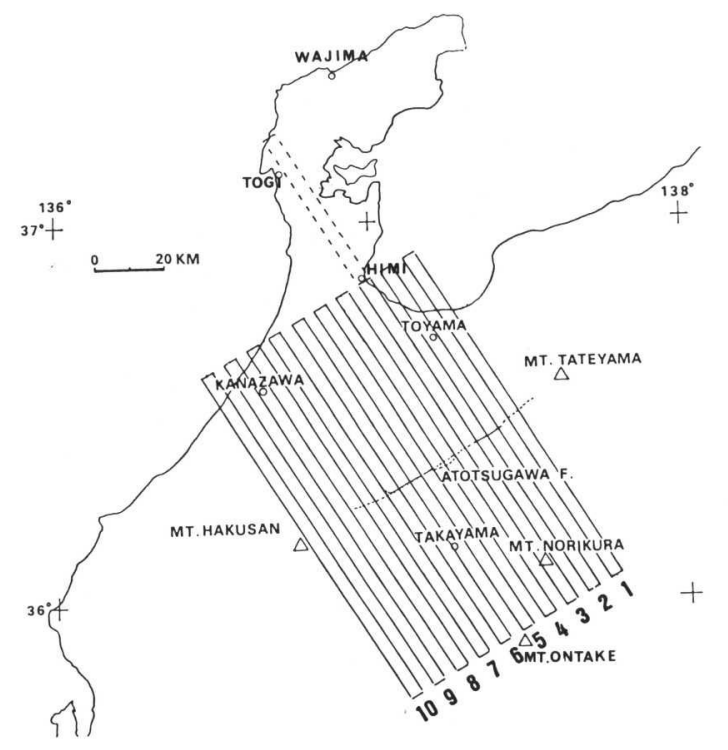

Fig. 5. Index map for Figs. 6, 7 and 8.

向にほぼ平行に分布している (Fig. 1). また, 富山・砥波 平野の低重力異常帯をはさんで北方には, 能登半島南部 の高重力異常帯が石動山から宝達山にかけて分布してい る.これらは, 跡津川断層の走向に垂直な方向に地殼構 造の大きな変化があることを暗示している.

\section{§3. 地形とブーゲ異常の断面}

断層周辺の地形とブーゲ異常の変化を見るため, 跡津 川断層の走向に直交した地形およびブーゲ異常の断面を 作成した，その位置を Fig. 5 に示す．各断面の全長は約 $110 \mathrm{~km}$, 幅は $4 \mathrm{~km}$ とした.この短冊の範囲内にある測 定点のブーゲ異常值と, 国土地理院による $500 \mathrm{~m} メ ッ$ 

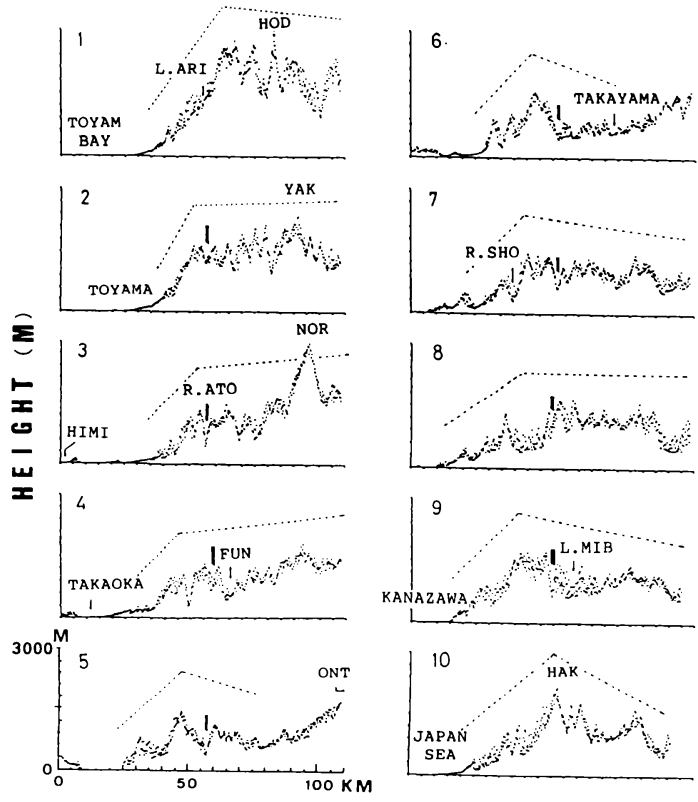

DI STANCE (KM)

Fig. 6. Topographic profiles drawn by the 500 $\mathrm{m}$ mesh mean height data. arrow: site of the Atotsugawa fault; dotted line: general trend of topographic relief; L. ARI: Lake Arimine; HOD: Mt. Hodakadake; YAK: Mt. Yakedake; R. ATO: River Atotsugawa; NOR: Mt. Norikura; FUN: Funatsu; ONT: Mt. Ontake; R. SHO: River Shogawa; L.MIB: Lake Miboro; HAK: Mt. Hakusan.

シュ平均標高データの高度とをプロットした．地形断面 のみをまとめて Fig. 6 に, ブーゲ異常断面を Fig. 7 に それぞれ示す。なお矢印は跡津川断層の位置を示す。

地形断面は, 一般的に, 跡津川断層の南側で高原状の なだらかな傾斜を示すのに対し，断層北側の平野部から 山地に至る傾斜は急峻である．この急変する地点は, 跡 津川断層の北側約 $25 \mathrm{~km}$ 以内にある.これと同様な指 摘は松原・他(1983)においてもなされている.

ブーゲ異常断面において，2.1 で指摘した跡津川断層 北側の高重力異常帯が, 断面「1」から「10」まで追跡で きる. また，全体の傾向を点線で示してあるが，跡津川 断首南側約 $20 \mathrm{~km}$ 以内の地点で, ブーゲ異常曲線の傾 きが急変している. 跡津川, 茂住, 牛首断層は, この長 波長のブーゲ異常の勾配が大きな地域 (「1」を除いて 12 $\sim 20 \mathrm{mgal} / 10 \mathrm{~km},\lceil 1 」$ は $60 \mathrm{mgal} / 10 \mathrm{~km})$ に位置し ているといえる. Figs. 6,7 に示されているように, 地形 は断面ごとにかなり変化するが, ブーゲ異常の全体の傾 向は「1」を除けば良く類似しており，跡津川断層をはさ んで $30 \mathrm{~km}$ の範囲内では特にそうである.この事は,

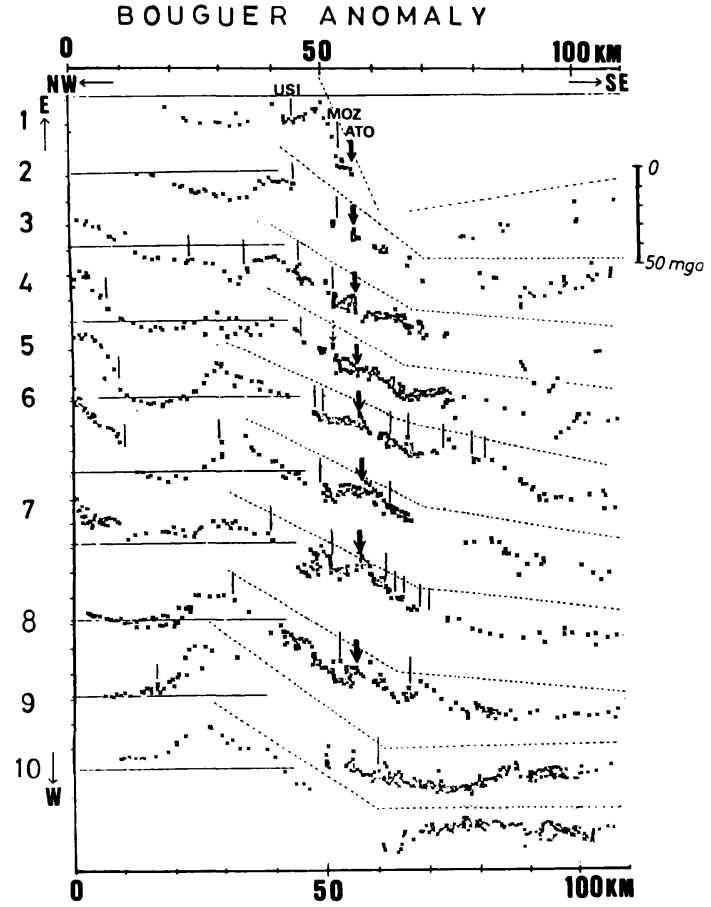

Fig. 7. Profiles of observed Bouguer anomaly. Vertical line: active fault; arrow: site of the Atotsugawa fault; dotted line: regional trend of Bouguer anomaly.

断層に垂直な方向の断面をとった時，表首を除けばそれ らを 2 次元モデルで近似できることを示している.

\section{§4. 地殼構造モデルの推定}

深部の地殼構造を論じる場合, ブーゲ異常の変化は密 度境界面の深さに比例して長波長となるため, できるだ け長い範囲の断面をとる必要がある. 一般的には深さに 対して 3〜5 倍以上の長さがとられる. また，深部の構 造になればなるほど密度層の数は普通多くなるが，一方 モデルの自由度を減らす観点からみれば，その数は少な いほど良い，そこで，密度層としては第四紀堆積岩，第 三紀堆積岩と火山岩, 先第三紀堆積岩と上部の花崗岩質 層, 下部の花崗岩質首, 玄武岩質層, 上部マントルの 6 層を仮定した。ささらに自由度を減らすためには，より下 位の層が地表に露出している断面が都合がよい，そのよ うな地域では地下の密度首の数が減るためである.

これらのことを考慮して，より長い断面がとれ，かつ, より下位の層にある花崗岩類と变成岩類がより多く分布 する地域を通る能登半島方向に延長した「3」の断面を 代表に選び，地殼構造モデルを推定した。 

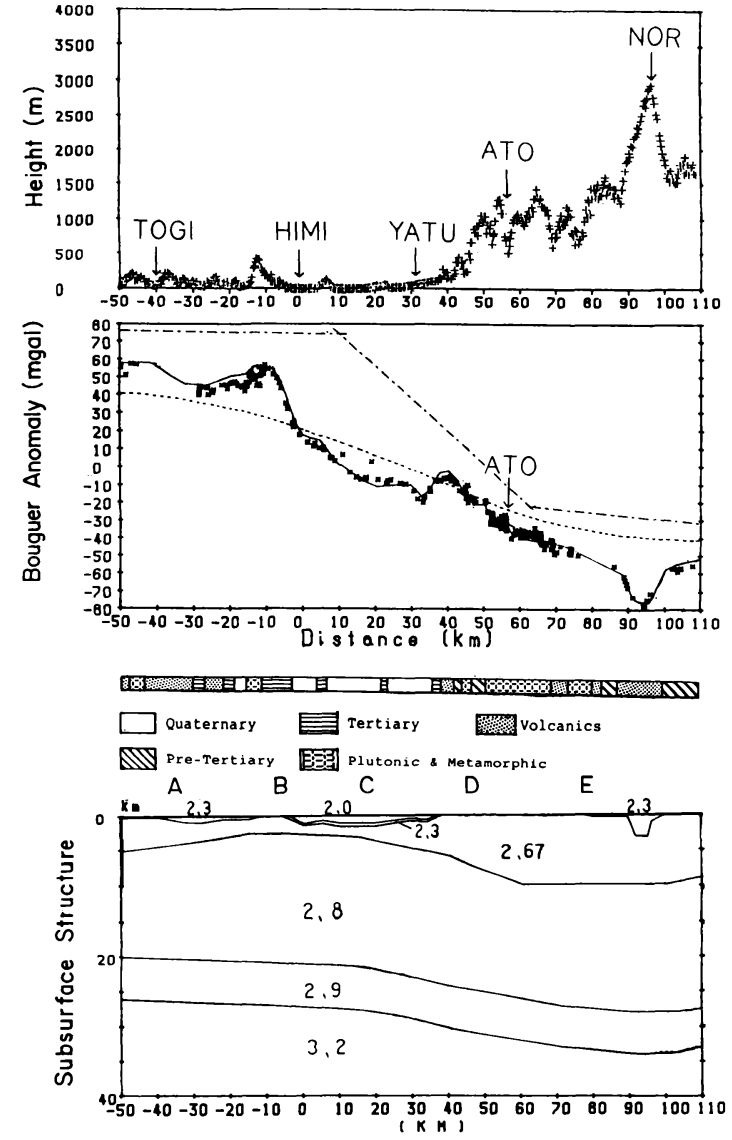

Fig. 8. Profiles of topography, observed Bouguer anomaly, geology and crustal structure model for the section 3 in Fig. 5. Variation of outcropped rocks along the section is shown in the middle of the figure. Broken line: a general trend; dotted line: $1^{\circ} \times 1^{\circ}$ mean Bouguer anomaly; solid line: theoretical Bouguer anomaly computed with the structure given in the lower diagram. TOGI: Togi; HIMI: Himi; YATU: Yatsuo; ATO: the Atotsugawa fault; NOR: Mt. Norikura.

\section{$4.1\lceil 3 」$ の断面のブーゲ異常の特徵とその解秎}

「3」の断面は, 能登半島北西部側から南東へ, 富来, 水見, 跡津川, 乗鞍岳を通る. この断面の平均標高, ブー ゲ異常および地表地質を Fig. 8 に示す.このブーゲ異常 断面をみると, 能登半島北西部( $-45 \mathrm{~km})$, 南東部( -10 $\mathrm{km})$, 跡津川断層北側 $15 \mathrm{~km}$ の地点 $(40 \mathrm{~km})$ が高重力 異常帯となっている. 断面沿いの地表地質分布とブーゲ 異常分布とを比較して見る限りあまり明瞭な対応は見ら れない.しかし，もう少し広く断面周辺の地質分布 (Fig. 3 参照) を見ると, 花崗岩類や変成岩類が高重力異 常帯の一部の地域に見られることから，この断面での高
重力異常帯はこれらの岩不が地表近くに存在するためだ と考えることができる. 一方, 能登半島中部, 富山・砺 波平野, 乗鞍岳付近の低重力異常帯の存在は, 第四紀・ 第三紀の低・中密度の堆積岩, 火山岩類が厚く分布する ためだと考えられる，それだけでなく，乗鞍岳の低異常 は，今回用いた補正密度がこの様な標高の高い火山地域 には不適当であることも関係している事を注意してお $<$.

\section{2 地款構造モデル}

以上のことをふまえて，実際に地款構造モデルを推定 してみる、これを行なうにあたって, 渥美・能登沖爆破 による地款構造モデル [AoKı et al. (1972)] および古瀬・ 河野 (1982) の重力異常からの地款構造モデルを参考と した. Ludwig et al. (1970)による密度と地震波速度の 関係から，P波速度 $5.5 \mathrm{~km} / \mathrm{s}$ 層の密度を $2.67 \mathrm{~g} / \mathrm{cm}^{3}$, $6.0 \mathrm{~km} / \mathrm{s}$ 層を $2.8 \mathrm{~g} / \mathrm{cm}^{3}, 6.6 \mathrm{~km} / \mathrm{s}$ 層を $2.9 \mathrm{~g} / \mathrm{cm}^{3}, 7.8$ $\mathrm{km} / \mathrm{s}$ の上部マントル層を $3.2 \mathrm{~g} / \mathrm{cm}^{3}$ とした. $6.6 \mathrm{~km} / \mathrm{s}$ 層の層厚は他に堆定するデータが無いから AoKI et al. のモデルと同じく $6 \mathrm{~km}$ の一定厚とした. さらに第四 紀，第三紀の推積岩，および火山岩の密度は，それぞれ $2.0,2.3,2.3 \mathrm{~g} / \mathrm{cm}^{3}$ とした.

Fig. 8 下に示した地殼構造モデルの一例を求めた手順 は次の通りである. まず， モホ面の起伏は KANAMORI (1963), 古瀬・河野 (1982) に従い, $1^{\circ} \times 1^{\circ}$ 程度の平均 ブーゲ異常で近似できるものとして，二次元タルワニ法 [TALWANI et al. (1959)] を用いて求めた. Fig. 8 のブー ゲ異常断面に点線で示した $1^{\circ} \times 1^{\circ}$ の平均ブーゲ異常值 は，この様にして推定したモホ面およびコンラッド面の 起伏のみによる理論值と同等である. 次に, 各測定点で のブーゲ異常値からこの $1^{\circ} \times 1^{\circ}$ の平均ブーゲ異常值を 引いた残差ブーゲ異常を求めた．モホ面の起伏による影 響をとり除いても，残差ブーゲ異常は断層北側でまだ相 対的に高重力異常となる. 跡津川断層周辺および先に述 べた高重力異常付近には密度 $2.67 \mathrm{~g} / \mathrm{cm}^{3}$ とした“基盤” 岩類が地表付近に分布すること，および玄武岩質層の層 厚を一定厚と仮定したため，その高重力異常の原因を上 部花岡岩質層と下部花岡岩質層との密度境界面に求めざ るを得ない. そのため, 深さ $5 \sim 10 \mathrm{~km} \mathrm{の} 2.67 \mathrm{~g} / \mathrm{cm}^{3}$ 之 $2.8 \mathrm{~g} / \mathrm{cm}^{3}$ 層の境界面の起伏に原因を求め,この理論 值が残差ブーゲ異常の高重力異常帯を通るように構造を 推定した. さらにその残差をとり, 低密度の $2.0,2.3 \mathrm{~g} /$ $\mathrm{cm}^{3}$ 層の構造を求めた。第四紀推積岩の層厚は, 坂本 (1966) を参考にして最大 $1 \mathrm{~km}$ とした. 全体の構造モデ ルによる理論値は, ブーゲ異常断面に実線で示してあ る.

このモデルは, 重力による地下構造解析法が含む様々 
な任意性から，多くの可能な解のうちのあくまでも一例 にすぎない，しかし，飛驒地域から能登半島南部にかけ て地殻構造（特に密度 $2.67 \mathrm{~g} / \mathrm{cm}^{3}$ と $2.8 \mathrm{~g} / \mathrm{cm}^{3}$ の境界 首）が急変しており，また，跡津川断層はこの地款構造 の急変化帯に位置していることを強く示唆している.こ こでは, ブーゲ異常の急変化帯の原因を比較的地表近く の上部花崗岩質層と下部花崗岩質層の境界面に原因を求 めたが、これ以外にも、コンラッド面またはモホ面の あっと大きな起伏で説明することも可能である.いずれ にせよ, 跡津川断層付近の長波長のブーゲ異常変化 (12 $\sim 20 \mathrm{mgal} / 10 \mathrm{~km})$ を説明するには, 跡津川断層周辺の 数 $\mathrm{km}$ より深部の地殼構造が急変しているためである と推定されることには変わりない。このことは地形と地 殻構造（あるいはブーゲ異常）が逆相関となり，アイン スタシーの観点からあ矛盾しない，むしそうだとする と, 跡津川断層などのもつ第四紀地殼変動から見た位置 を次の様に理解できるだろう。つまり, 立山, 跡津川断 層, 白山, 阿寺断層, 飛驒山脈東縁部などで象徵される 地域 (飛驒三角形) が, 東西圧縮によるブロック的な地 形の隆起に伴い, アイソスタシーの状態を保つよう地壳 深部に“根”をはり，発達してきたのであろう．跡津川 断層はその飛驒三角形の造構運動の一つの境界部に位置 しているといえよう.

\section{§5.謝辞}

本研究を進めるにあたって, 跡津川断層周辺の詳細な デー夕を提供していただいた金属鉱業事業団に深く感謝 いたします。また図をトレースしていただいた当教室の 中村健二氏に感謝します。計算には, 金沢大学計算機セ ンター(FACOM M170F) を使用した。

\section{参考文献}

Aoki, H., T. Tada, Y. Sasaki, T. Ooida, I. Muramatu, H. Shimamura and I. Furuya, 1972, Crustal structure in the profile cross central Japan as derived from explosion seismic observations, J. Phys. Earth, 20, 197-223.

跡津川断層掘削調査団, 1983 , 跡津川断層におけるトレ ンチ掘削調查（速報），月刊地球，5, 335-340.

江坂照也・古本宗充, 1981 , 重力からみた阿寺断層の破 砕帯, 月刊地球, 3, 211-215.

古瀬慶博 - 河野芳輝, 1982 , 中部地方北西部の重力異常 と地下構造, 地震 $2,35,547-556$.

古瀬慶博・河野芳輝, 1984, 本州中部地域のアイソス夕 シ一, 地震 $2,37,569-578$.

Geodetic Department, Geographical Institute, 1985, A New Bouguer anomaly map of Japan (except Hokkaido district), Bull. Geograph. Surv. Inst., 29, 102-113.
Hirokawa, O. (chief ed.), 1978, Geological Map of Japan, $1: 1,000,000$ (2nd ed.), Geological Survey of Japan.

KANAMORI, H., 1963, Study of the crust-mantle structure in Japan, Part 1. analysis of gravity data, Bull. Earthq. Res. Inst., 41, 743-760.

活断層研究会, 1980 , 日本の活断層分布之資料, 東京大 学出版会, 363 pp.

金属鉱業事業団, 1972 , 昭和 47 年度広域調查長棟地域 重力調查報告書, $33 \mathrm{pp}$.

金属鉱業事業団, 1976 , 昭和 51 年度広域調査飛驒地域 重力調查報告書, $39 \mathrm{pp}$.

金属鉱業事業団, 1978 , 昭和 53 年度広域調査飛驒地域 重力調查報告書, $32 \mathrm{pp}$.

国土地理院，1976, 日本重力基準網 1975 の設定, 測地 学会誌, 22, 65-76.

河野芳輝, 1978, 固体地球物理学に関係するデータファ イルとプログラムについて（I）, 地震 2, 31，251264.

河野芳輝 - 日比 猛 - 久保昌之 - 角南基亮 - 道上 収 啮谷恭二・古瀬慶博・鈴木敬二郎, 1982, 中部日本北 部の重力異常 (1), 地震 $2,35,539-545$.

河野芳輝, 1983, 中部日本北部の重力異常 (2) 地形, 地 震活動, 活断層, 構造線との比較, 地震 $2,36,247-$ 253.

河野芳輝・久保昌之, 1983 , メッシュ状平均標高データ を用いた地形補正計算, 測地学会誌, 29, 101-112.

Kono, Y., T. Hibi, M. Kubo, O. Michigami, K. Shibuya, M. Sunami, K. Suzuki and N. Furuse, Gravity anomaly over the northern part of central Japan (1), Sci. Rept. Kanazawa Univ., 27, 71-83.

Ludwig, W. J., J. E. Naff and C. L. Drake, 1970, Seismic refraction, The Sea (ed. A. E. MAxwell), WileyInterscience, New York, 4, part 1, 53-84.

松田時彦, 1966, 跡津川断層の横ずれ変位, 地震研究所 彙報, 44, 1179-1212.

松原勇・川畑新一・川崎一朗, 1983, 跡津川-牛首断 層系と長波長地形変化, 地震学会講演予稿集, No. 2, 97.

村上英記・山田功夫・小林 潮, 1984, 活断層に伴う全 磁力異常——跡津川断層・阿寺断層における全磁力調 查, 地震 $2,37,397-405$.

坂本 享, 1966, 富山積成盆地南半部の新生界とその構 造発達史, 地質調査所報告, No. 213,27 pp.

TAlwani, M., J. L. Worzel and M. Landisman, 1959, Rapid gravity .. computations for two-dimensional bodies with application to the Mendocino submarine fracture zone. J. Geophys. Res., 64, 49-59.

宇佐美龍夫 - 東京大学史料編纂所 - 京都大学防災研究所 上宝地款変動観測所, 1979, 飛驒地震 (安政 5 年 2 月 26 日）と跡津川断層, 地震予知連絡会会報, 21, 115119.

和田博夫 -三雲 健 - 小泉 誠, 1979, 飛驒地方北部特 に跡津川断層と発震機構, 地震 $2,32,281-296$.

Yamamoto, A., K. Nozaki, Y. Fukao, M. Furumoto, R. Shichi and T. EzakA, Gravity survey in the central ranges, Honshu, Japan. J. Phys. Earth, 30, 201-243. 